\title{
Corruption Prevention and Economic Growth: A Mediating Effect of Rule of Law
}

\author{
Qian Hongdao ${ }^{1}$, Ayesha Mumtaz ${ }^{2}$ Hamid Mukhtar ${ }^{2}$, Hafiz Abdul Rahman Saleem², Sonia Azam² \\ ${ }^{1}$ Professor of Law, Guanghua Law School, Zhejiang University, Hangzhou, China \\ ${ }^{2}$ Doctoral Candidates of Law, Guanghua Law School, Zhejiang University, Hangzhou, China \\ Corresponding Author: Ayesha Mumtaz, Doctoral Candidates of Law, Guanghua Law School, Zhejiang University, \\ Hangzhou, China.
}

Received: January 2, 2018

doi:10.11114/ijsss.v6i2.2946
Accepted: January 22, $2018 \quad$ Available online: January 23, 2018

URL: https://doi.org/10.11114/ijsss.v6i2.2946

\begin{abstract}
This article is based on the mediating effect of rule of law between control of corruption and economic growth in China. Many empirical studies have been conducted on the relationship of corruption with economic growth, income, democracy, education, employment rate and the likes. Most of them are based on linear relationship and evaluate the impact of corruption and corruption prevention on different economic and social variables. But the study under consideration is focusing upon the role of rule of law in control of corruption and economic growth in China. It puts forth a question that what kind of effects rule of law put on economic growth and corruption prevention. The top seven economies of the world have been selected and data has been extracted from the Worldwide Governance indicators of the World Bank. In order to address the above question, the study was divided into two major parts. First, the author has applied regression analyses to see the relationship among the economic growth, rule of law and corruption; and also the impact of economic growth and control of corruption on rule of law. Then, mediation analysis has been conducted to see if rule of law plays a role in control of corruption and economic growth. The results show that economic growth significantly improve the level of control of corruption and rule of law plays a partial intermediary role in the process of economic development to enhance the corruption prevention. Second, the author has discussed the condition of rule of law and corruption in the era of the current leader, Xi Jinping and before 2012.
\end{abstract}

Keywords: rule of law, corruption, economic growth, China

\section{Introduction}

Rule of law has now been considered as a central indicator for corruption prevention and also an explanatory variable for economic growth. Corruption is highly contested and deeply rooted phenomenon. It has become a hot issue and universal problem in today's modern world. Many researchers show that corruption has a negative impact on the economic growth, rule of law, quality of education, prices, trade and so on. (Ades \& Di Tella, 1997; Ahmet, 2012; Bayar, 2011; Berkman, 1988; Dridi, 2014; Goel \& Rich, 1989; Gyimah-Brempong, 2002; Lee, 1981; Mo, 2001; Podobnik \& 2008; Sung, 2004; Swamy, Knack, Lee, \& Azfar, 2001; Van Rijckeghem \& Weder, 2001). In the early 1980s, many international organizations and institutions work jointly to produce big data of corruption and provide a ground for empirical research in this field. Many empirical studies have been done to examine the nature of the relationship of corruption with other variables. Corruption perception index of transparency international, Bribe payer's index, worldwide governance indicators of the World Bank, Corruption perception index of transparency international, and Rule of Law index of world justice project are the most widely recognized indices to measure the corruption and governance indicators worldwide.

China is going through tremendous legal, economic, social and political reforms for more than thirty years. During these thirty years, China has achieved marvelous success in economic sector as its GDP came up as a second highest in the world. ${ }^{i}$ Along with the GDP progress and open market reforms, corruption in China has emerged as biggest economic crime and the numbers of corruption-related crimes are increasing day by day. China's leadership has now turned its focus towards fighting the corruption by strengthening the institutions. The anti-corruption reforms boosted since $18^{\text {th }}$ national CCP congress held in Beijing in November 2012. ${ }^{\text {ii }}$ China's current leader Xi Jinping has led the foundation of the anti-corruption reform era by making different policies. The main approach of his anti-corruption 
campaign is to target both "Tigers and Flies" which means to target corrupt local and national level government officials. Rule of law is also one of the main focused reform areas in transitional China. It is also a highly contested phenomenon and it is not easy to define the limits of the rule of law in China. China has a long imperial history and there remained tensions between the li(rituals) and fa(Lance, Butts, \& Michels $)^{i i i}$. Chinese legal traditions have a great impact on the legal life of modern China. As an official matter, both the party's constitution and the 1982 constitution have confirmed the basic principle of a government ruled by law. The law is the supreme one, and everyone is equal before the law. ${ }^{\text {iv }}$ In addition, in 1996 Jiang Zemin adopted a new official document, which formulated the guidelines for governing the country according to law to establish a socialist state law (hereinafter referred to as the "amendment of the constitution"), which was then incorporated into the Constitution. ${ }^{v}$ Reforms in combating corruption and rule of law are going parallel in China but it is too early to say that China has fully achieved its goal of legal reforms and corruption prevention.

The main objective of this article is to analyze the role of rule of law in control of corruption and economic growth in China. The author has set two hypotheses to address the main problem statement. First hypothesis is that it is possible to improve the economic growth by reducing corruption. Secondly, it hypothesized that rule of law plays an intermediary role in controlling the corruption, which, in turn, stimulates the economic growth. To verify the hypotheses, this paper uses the data of corruption prevention, rule of law and economic growth indicators from worldwide governance indicators. Section 1 of the article describes the relationship of rule of law, economic reforms and corruption in China with the help of theoretical background and by reviewing the existing empirical literature on this subject. Section 2 describes the empirical relationship between corruption and rule of law and the role of economic growth. Regression analysis is applied on the data of top seven economies ${ }^{\mathrm{vi}}$ of the world including China to verify the hypothesis. Section 3 highlights the condition of corruption and rule of law and economic growth before 2012 in China. Furthermore, the condition of corruption and rule of law and economic growth since 2012 in China discussed in section 3 along with the facts and figures. Finally, the authors concluded in section 4 of the paper.

\section{Rule of Law, Economic Growth and Corruption Prevention in China}

\subsection{Historical Background and Literature Review}

Reducing corruption and promoting rule of law by making economic growth stable is the biggest challenge for the governments. Technical and political problems arise while creating grounds for officials to serve the public interest rather than private interest. Economic growth, rule of law and corruption are closely related to each other and rule of law is considered the most important indicator of governance and control of corruption is a key to foster the rule of law and they both have an effect on economic growth ${ }^{\text {vii }}$. This section provides some theoretical grounds and review of the existing studies to understand the relationship between corruption, rule of law and economic growth.

Since Deng Xiaoping started the policy of reform and opening up in 1978, he urged China to adhere to the rule of law and economic reforms. One of the surveys of European chambers of commerce in China (EUCCC) considered the rule of law as most important drivers for China's economic performance and growth. ${ }^{\text {viii }}$ With the rising concepts of globalization and industrialization, the rule of law became an essential entity to almost all countries of the world. Since opening up the economy and market reforms, the demand for the adherence to the rule of law in China has been increasing day by day. One of the reasons for the increasing efforts to foster rule of law is to provide and ensure the transparent, lean and clean environment for the investors to invest in China. ${ }^{\text {ix }}$ Many western entrepreneurs and companies consider the rule of law as a very important driver for the safe grounds in China for their investment. Though the economic performance of China is remarkable for the past thirty years there is still need of some more policies to transform it to a clean, transparent and highly efficient modern government that operated under the rule of law. China has achieved tremendous success in the economy over the past thirty years and setup example for other countries. The World Bank suggested China achieve the sustainable growth and consider it mandatory to implement the rule of law. ${ }^{\mathrm{x}}$ The report put emphasis that sustainable economic development requires a "government that operates under the rule of law'.(Samuels, 1998) Following the Deng Xiaoping, the next president, Jiang Zemin, in 1997, introduced government in accordance with the law and in 1999; China formally introduced the concept of the rule of law in its constitution. ${ }^{\text {xi }}$ Thus the concept of rule of law is new to Chinese government but some Chinese leaders already used alternate terms like democracy or legal system to achieve the real goal of rule of law in China. ${ }^{\text {xii }}$

After the opening up reforms, China has boosted its progress and put its emphasis to attract the outer world towards China to attract foreign investment (ECKHOLM, 2000) $)^{\text {xiii }}$. Hu Jintao, the next becoming president before taking into power as a president in 2003 said in his speech that "we must build our system on rule of law and should not pin our hopes on any particular leader". xiv

After analyzing the statements of different Chinese leaders and the involvement of international institutions for the recognition of rule of law in China we may conclude that there is a deep connection between rule of law and economic 
growth. These both terms have been used side by side since open market reforms after 1978. Furthermore, we also cannot ignore the interwoven relationship among the rule of law, market economy and the corruption in China. With the growing intention of moving towards rule of law system, the Chinese government has also intensified its anti-corruption efforts. At the same time, the progressive reforms of the economy, politics and administration have also contributed significantly to the fight against corruption. Literature shows that in contemporary China, the increasing rate of corruption was due to dual economic systems. (Sun, 2004) The dual price system and the coexistence of resource allocation by the market and state plan are the main source of income for the Chinese economy (He, 2000).

However, the acceleration of market-based reform and restructuring of state-owned enterprises has played a key role in reducing corruption and related economic crime. Corruption has often been considered a useful subject for critics of repressive regimes, but its significance in China is particularly profound. Not only did it weaken the legitimacy and ability of the state to govern, but it also provided the opportunity for a possible change from a traditional, man-made society to a rational and legal society governed by the law.(Hao \& Johnston, 1995)

The white paper of 2008, declared democracy and rule of law as essential factors for economic and social development. ${ }^{\mathrm{XV}}$ Two aspects of the rule of law are considered particularly relevant in anti-corruption discourse; good governance and the deterrence of corruption. Since 1978, when China altered its economic policies and adopted an open market policy, the rise of corruption in China has also been highlighted by many scholars. ( Ting Gong, 2002, Guzin Bayar 2012, Carlos D. Ramirez, 2014).Despite the obvious relevance of the rule of law for anti-corruption objectives, the literature does not provide much material in this area (Carothers 2003(Bertot, Jaeger, \& Grimes, 2010; Carothers, 2003; Pelizzo \& Stapenhurst, 2004). Most of the interventions point to two issues: supporting the implementation of important laws such as anti-corruption legislation and the strengthening of programs and projects in law enforcement agencies such as police, prosecutorial, police and judicial agencies, and recently, special anti-corruption bodies (Carothers, 2003).

Much of the literature see Rule of Law as a precondition or a feature of, a heal thy democracy; without Rule of Law the careful separation and balancing of powers in a democratic constitution is undermined, and the state machinery will be unable to provide Good Governance as intended, hindering development.\{Przeworski, 2003, Habermas, 1996, Rigobon, 2005, Carothers, 1998, O'Donnell, 2004 \} Accordingly, rule of law has been a major component in good governance and development cooperation strategies. Since the 1990s, with the rise of the anti-corruption struggle, in addition to the "good governance "perspective, the rule of law is also seen as a means of fighting corruption; a clear and correct code of conduct and a discouragement of openness, criminal investigation, prosecution and conviction and the prospect is to prevent corruption in the public sector. In addition, the broader efforts already made in good governance and the rule of law have focused on the introduction of more professional anti-corruption legislation, agencies and a new generation of interventions. If we see the results concerning rule of law interventions, some successes are recognized. Anti-corruption is becoming an integral part of development policy frameworks. Awareness of corruption as a development problem and as a symptom of poor governance has increased. China along with many other countries have signed the United Nations Convention against Corruption and formally adopted anticorruption policies, strategies and laws. ${ }^{\mathrm{xvi}}$ In general, however, the western literature laments the few results that can be shown for all the efforts. After the 1989 Tiananmen Square event, the new Chinese leaders have given priority to anti-corruption work on their agenda and strengthened anti-corruption efforts to foster the rule of law and economic reforms.

After analyzing and summarizing the above arguments, we may conclude that rule of law has a strong link with economic reforms in China. Moreover, when the concept of the rule of law has been recognized and declared mandatory for economic reforms by the top leadership of China, they have also encountered the corruption as a serious economic crime. Although, we couldn't find much literature about the direct relationship of rule of law and corruption on the basis of the above-mentioned arguments and studies we may assume that rule of law has a mediatory factor between the corruption prevention and economic growth. In the following section, the author highlights some empirical studies about the relationship of corruption with different variables.

\subsection{Empirical Studies on Corruption}

Many empirical studies have been done to see the relationship of corruption with different variables. Different corruption indexes made it possible for researchers to empirically analyze the relationship and impact of corruption on different variables. Although most of the data is based on the subjective perceptions of people as corruption has an ambiguous nature so the perception based data is acceptable for further use. Due to its prevalence in almost every sector, many research studies have been conducted on this issue with different perspectives. The legal scholars see the relationship between the level of corruption and the strength of the legal system of the country. Economists see the relationship between corruption and its impact on the income, education, growth, governance and so on. This section provides the review of some existing literature about corruption and its relationship with different variables. 
Some empirical studies have been done to analyze the relationship between corruption and economic growth. Mo in 2001, conducted an empirical study about the role of corruption in economic growth and the transmission channels through which corruption affects the GDP growth rate. The results of his study show that corruption has negative effect on the share of investment and human capital. Furthermore, income inequality also has a negative effect on economic growth. He concluded that the increase in corruption level reduces the economic growth and the most important channel through which corruption affects economic growth is political instability (Mo, 2001).

Gyimah-Brempong, in 2002, conducted a study to see the effect of corruption on economic growth and income distribution in African countries. He used dynamic panel estimator to generate the results and the outcome of this study showed that corruption decreases economic growth directly and indirectly through decreased investment in physical capital. He also concluded that the increase corruption is positively correlated with income inequality.(Gyimah-Brempong, 2002).Another study analyzes the relationship between corruption and economic growth. The author used a five-year data of corruption perception index to analyze the dependence between the GDP per capita growth rate and changes in the corruption index. The results show that increase of CPI by one unit leads to an increase of the annual GDP by $1.7 \%$. (Podobnik \& 2008)

A study conducted by Treisman, using panel data of developed and de veloping countries, shows that the countries that are more developed and more open to foreign trade have less corruption. Although the current level of democracy in a country is a significant factor affecting corruption, the countries that have a long history of democracy and rule of law have significantly lower levels of corruption (Treisman, 2000). Similarly, In the article by Ades and Di Tella (1997), a number of panel and cross-section regressions analysis have been done and results, in general, show that more active industrial policy of the government is significantly correlated with higher levels of corruption. The degree of political rights in the country has no significant effect on corruption and education level. The degree of openness to foreign trade and security level of the country have significantly negative relationships with the level of corruption (Ades \& Di Tella, 1997).

In a study about causes of corruption, the author examined cross-sectional data of 107 countries; reach the same conclusion with Treisman (2000) about the effect of democracy tradition on decreasing corruption. Pelligrini and Gerlah (2008) have different findings as compared to Ades and Tella, that political instability increases corruption and prevalence of the newspapers decreases it (by informing the people about corruption cases and thus serving as a way of discouragement for corrupt people). There is not a statistically significant relationship between the government interventions the economy and the corruption.(Bayar, 2011)

Rijckeghem and Weder examined panel data of 31 countries from 1982 to 1994, find a statistically significant negative relationship in the long term between corruption and the ratio of public sector employees' wage level to the wage level of the employees in the private productive sectors. On the other hand, authors cannot find a relationship between either education and corruption or gross domestic product per capita and corruption. (Van Rijckeghem \& Weder, 2001).

Tosun also examined the relationship between corruptions with different variables by using data from 44 countries for 1982-1995. He concluded that rule of law, quality of bureaucracy and public expenditures have a decreasing effect on corruption. Level of inflation, national income growth, and wage level of public employees seem not to have a statistically significant effect on corruption. (Karagöz \& Karagöz, 2010) Similarly, Zakaria finds for Pakistan that openness to foreign trade decreases corruption. Moreover, corruption decreases with increasing education level, national income, political freedom and the decreasing level of government intervention in the economy. (Zakaria, 2009)

Broadman and Recanatini examine 26 countries in transition, showing growing barriers to entry in markets, an increasingly ineffective legal system, and an increasingly poor infrastructure services, linked to rising levels of corruption. The impact of increased democratization on corruption is declining, while the coefficient of openness is statistically insignificant. The coefficient of per capita GDP is negligible, and elite recruitment and education make a lot of sense in explaining a measure of corruption. The impact of all the three variables on corruption is descending. On the other hand, the measurement of occupational, wage and ethnic diversity is negligible for both measures of corruption.(Broadman \& Recanatini, 2001)

Goldsmith's (1999) sample study of 34 low- and middle-income countries shows that GNP per capita has a significant declining effect on corruption: increased economic liberalization and increased national power are also important factors in reducing corruption. Although other variables are less important, the highest levels of political democratization are also associated with the reduction of corruption. (Goldsmith, 1999) (Goldsmith, 1999)

(Berkman (1988) mentions that the relationship between traditional values and corrupt tolerance found that those with higher traditional values tolerated corruption, while lower traditional bonds tolerated less corruption, suggesting that older who have less education tolerate more corruption and younger and more educated are more tolerant of corruption.(Berkman, 1988; Lee, 1981) 
According to data from the United States, Goyle and Ridge show that the probability of conviction and the severity of punishment are reducing corruption. The variable regulation does not have a significant effect. Raising the salary level of public officials has little effect on the level of corruption. The coefficient of unemployment factor is positive and significant, which may reflect the increase in bribery during the economic downturn. Finally, the advertising variables are important and positive, most likely due to an increase in the number of ads that lead to increased corruption by increasing the future personal discount rate (Goel \& Rich, 1989). The UNDP report on corruption in Asia and the Pacific states that the total cost of small-scale corruption for poor households is in fact very high and that the aggregate of all large persons provides a large sum of money for Bribery (UNDP, 2008 Month). For example, in Bangladesh, 60\% of the city's inhabitants pay money for access to water (June, Chowdhury, Heller, \& Werve, 2008). Swamy explores corruption with the gender dimension in her essay "Gender and Corruption" and asks the following evidence: (i) women are less likely to collude with corruption; (ii) women managers are less involved in bribery, (iii) The governments or the more female representatives in the market, the lower the level of corruption. This is based on microdata from the so-called Global Values Survey and the Georgia Trade Survey, as well as cross-border big data. These findings are consistent with criminological studies that found that corruption per 100,000 white-collar male workers is higher than that of women of all ages and that men have higher rates of crime in different age groups, countries and types of crimes. Several theories have been proposed to explain these differences, but the authors point out that these data do not allow the validation of any theory.(Swamy et al., 2001)

The study of the relationship between inflation and corruption examined the impact of inflation, growth, trade gaps, legislative quality, government effectiveness, political stability and accountability for corruption using five-year panel data from 97 countries with different income levels. According to empirical data, inflation has had a statistically significant positive impact on the corruption of three different income groups in 97 countries (Ahmet, 2012).

Similarly, another study empirically examined the relationship between various indicators of education and corruption through cross-sectional regression analysis. The results show that there is a strong correlation between high school enrollment and corruption, but the relationship between the quality of the education and corruption is modest (Dridi, 2014).

The above empirical studies have shown the relationship between corruption and corruption prevention with many different variables. This study is adding its contribution in the existing empirical literature about the nature of the relationship between corruption, rule of law and economic growth in China. The complete model is elaborated in the next section.

\section{Empirical Model and Data Analysis}

\subsection{Research Design}

The study is quantitative in nature. It is a mediation analysis in which three variables are under consideration: Control of corruption as an independent variable, economic growth as an outcome variable and rule of law as a mediator or intervening variable. This section provides a complete model of the mediating role of rule of law between corruption prevention and economic growth. The researcher has created two main hypotheses:

Hypothesis 1: If corruption is reduced, Economic growth will be increased.

Hypothesis 2: Rule of law plays an intermediary role in controlling the corruption, which, in turn, stimulates the economic growth

\subsection{Procedure of Analyses}

In the present study, a four-step approach has been adopted in which regression analyses are applied and significance of coefficients is measured (Baron \& Kenny, 1986). The first three steps are conducted to see the relationship between variables and the last one is performed for testing mediation. The proposed model contains following four steps:

\section{Model-1}

The first step is to establish a relationship between economic growth and corruption prevention. The regression line for testing the impact of economic growth on the prevention of corruption is as follows:

$$
\text { Coc, } \mathrm{t}=\alpha_{0}+\alpha_{1} \text { GDPi, }{ }_{\mathrm{t}}+\Sigma \text { Year }+\varepsilon \mathrm{i}, \mathrm{t} \ldots
$$

Where Coc is explained or outcome variable which refers to the level of control of corruption; GDP is an explanatory or predictor variable which refers to economic development. According to Baron \& Kenny, if the estimated coefficient $\alpha_{1}$ is significantly positive or relationship between the underlying variables exists, then the subsequent test would be continued. 


\section{Model-2}

The second step is to assess the impact of economic growth on the rule of law. In order to serve this purpose, simple regression analysis has been performed with mediator predicting the outcome, and the following regression line has been generated:

$$
\text { Rol, } \mathrm{t}=\alpha_{0}+\alpha_{1} \mathrm{GDP}_{\mathrm{i}}, \mathrm{t}+\Sigma \text { Year }+\varepsilon \mathrm{i}, \mathrm{t} \ldots
$$

Where RoL denotes Rule of Law. It is the intermediary variable or simply a mediator. It is also explained variable here. GDP is an explanatory or independent variable, refers to economic development. If the estimated coefficient $\alpha 1$ is significantly positive, indicating that the explanatory variable well predicts the outcome variable, then the next step would be likely.

\section{Model-3}

In the third step, the relationship between predictor and mediator is expected to be calculated. In order to see the impact of the rule of law on the corruption prevention, a third regression line is established:

$$
\text { COCi, } \mathrm{t}=\alpha_{0}+\alpha_{1} \text { ROLi, } \mathrm{t}+\Sigma \text { Year }+\varepsilon \mathrm{i}, \mathrm{t}
$$

In the line above, $\mathrm{Coc}$ is explained variable, which refers to the level of control of corruption and RoL is an intermediary variable, which refers to the level of the legal system. If the estimated coefficient $\alpha 1$ is significantly positive, indicating that there may be an intermediary effect, and independent variable predicts the mediator well, then the subsequent test would be possible.

\section{Model-4}

Fourthly, regression analysis is conducted to test the role of the Rule of law as an intermediary variable. Mediation analysis is performed to see whether RoL mediates between Coc and GDP or not. Control of Corruption (explained variable), Economic growth or GDP (explanatory variables) and Rule of Law (intermediary variables) all are included in the model to establish another equation:

$$
\text { COCi, } \mathrm{t}=\alpha_{0}+\alpha_{1} \text { GDPi, } \mathrm{t}+\alpha_{2} \text { ROLi, } \mathrm{t}+\Sigma \text { Year }+\varepsilon \mathrm{i}, \mathrm{t}
$$

In this equation, if the absolute value of the estimated coefficient $\alpha 1$ of the explanatory variable GDP or the significance of the estimated coefficient $\alpha 1$ is compared with the regression result of the regression line-1, and the difference is found between the two i.e., regression coefficient is decreased, it is proved that there is a mediating effect or the mediation is supported.

In the regression line 1 through $4, \alpha_{0}$ is a constant term, $\alpha_{1}, \alpha_{2}$ are the coefficients to be estimated and $\varepsilon$ is the error term. The subscript I for each variable represents the country, $t$ represents the period. In order to reduce the impact of macroeconomic changes on research results, the model controls the annual effects.

\begin{tabular}{|c|c|c|c|}
\hline Variable type & Variable code & Variable name & Method and description of variable value \\
\hline Explained/interpreted variable & $\mathrm{COC}$ & Control of corruption & Corruption Control Index \\
\hline Interpreting variables & GDP & Economic development & Gross Domestic Product / total population \\
\hline Mediating variables & RoL & Rule of Law & Rule of Law Index \\
\hline Other variables & Eyear & Annual Virtual variable & Belongs to a year. 1 , otherwise 0 \\
\hline
\end{tabular}

The specific explanation of each variable in the model is shown in Table 1.

Table 1. Variables and explanations

Note: The variables are standardized with the total assets of the enterprise.

The sample of this paper is the seven largest economies in the world, namely China, the United States, Japan, India, Germany, France and the United Kingdom. The sample period is 2007-2016, and a total of 70 observations are obtained as panel data.

\subsection{Results of Regression Analysis}

The researcher has used Stata12.0 software for regression analysis. The regression results are shown in Table 2. 
Table 2. Regression Results

\begin{tabular}{lllll}
\hline Variable & Model ( 1 ) & Model (2) & Model (3) & Model (4) \\
\cline { 2 - 5 } Constant term & Estimated coefficients & Estimated coefficients & Estimated coefficients & Estimated coefficients \\
& $-0.5234^{* * *}$ & $-0.2538^{* * *}$ & $-0.2248^{* * *}$ & $-0.2990^{* * *}$ \\
GDP & $(-3.92)$ & $(-2.18)$ & $(-2.67)$ & $3.35)$ \\
& $4.61 \mathrm{E}-5^{\mathrm{xv1} 1 * * *}$ & $4.21 \mathrm{e}-5^{* * *}$ & & $8.91 \mathrm{e}-6^{* *}$ \\
RoL & $(23.27)$ & $(24.38)$ & & $(2.10)$ \\
& & & $1.0765^{* * *}$ & $0.8838^{* * *}$ \\
Syear & & & $(36.24)$ & $(9.20)$ \\
Observed values & Control & Control & Control & Control \\
Adj-r & 70 & 70 & 70 & 70 \\
F value & 0.8854 & 0.8946 & 0.9498 & 0.9526 \\
\hline
\end{tabular}

Note: $\mathrm{t}$ values in brackets, ${ }^{*}, * *, * * *$ represent significance (two-tailed) at $10 \%, 5 \%, 1 \%$ confidence level, respectively.

It is presented in Table 2, for model-1, the estimated coefficient of explanatory variable GDP is 4.61E-5, which is significantly positive at the confidence level of $1 \%$. It indicates that economic growth can significantly improve the level of prevention and control of corruption. The results showed that GDP is a significant predictor for COC. Thus hypothesis 1 is verified.

Similarly, in model-2, the estimated coefficient of the explanatory variable GDP is $4.21 \mathrm{E}-5$, which is statistically significant at the $1 \%$ confidence level, describing that economic growth can significantly raise the rule of law. Therefore, it is proved that GDP well predicts the rule of law.

Again in model-3, the estimated coefficient of mediating variable Rule of law is 1.0765 , which is significantly positive at the $1 \%$ confidence level. It depicts that the rule of law can significantly improve the level of prevention and control of corruption.

Finally, in model-4, the estimated coefficient of explanatory variable GDP is $8.91 \mathrm{E}-6$, which is significantly positive at $5 \%$ confidence level. The estimated coefficient of mediating variable RoL is 0.8838 , which is significant at $1 \%$ confidence level. When compared with the result regression line-1, the absolute value of the regression coefficient of explanatory variable GDP is decreased after adding intermediary variable RoL. It means that the level of Rule of law plays a partial intermediary role in the process of economic development to enhance the impact of prevention and control of corruption. As a consequence, Hypothesis 2 is supported.

To summarize, we can conclude that the corruption prevention improve the economic growth and the rule of law as a mediator plays a partial intermediary role between the corruption prevention and economic growth.

\subsection{Robustness Test}

Taking into account the different values of the variables in the model, we use the legal hierarchy to replace the original rule of law index when we measure the level of the rule of law. When we measure the level of the prevention and control of corruption, we use the anti-corruption level to replace the previous one. Then re-enrolled in the model (1) - (4) for regression analysis and found no significant changes in the results.

\section{Rule of Law and Corruption in China before 2012}

The previous sections threw some light on the relationship of rule of law and corruption by relating it to the emergence of the open market and economic reforms in China theoretically and statistically as well. In this section we proceed more details by using some statistics about the rule of law, corruption and economy in China before 2012. The reason to start from the situation and progress of these indicators before 2012 is to deeply understand the nature, extent and emergence of these reforms in transitional China. The process of the legal reforms was started in China immediately after the Mao's Cultural Revolution period. Deng Xiaoping introduced a new 'open door policy' and opened the doors of China for the foreign world. He focused not only to boost economic reforms but also brought legal reforms in line with other reforms. From 1976 to 1998, the NPC and its standing committee approved 337 laws and congresses at various levels and the government issued more than 6,000 provisions. In contrast, only 134 laws were passed between 1949 and 1978, and only one law passed between 1967 and 1976 during the Cultural Re volution. In addition, of 134 laws passed between 1949 and 1978,111 were declared null and void and many others were revised during the post- 1978 reform period. ${ }^{\text {xviii }}$ Along with the economic and legal reforms, anti-corruption campaigns also became part of the reforms agenda of CPC's leadership. Efforts have put on the institutional building. The ministry of justice which was dismantled in 1959 reestablished in 1979. Laws schools and legal institutions were reopened and reorganized. In particular, economic and legal reforms were continued and improved day by day. Here we may concern that the increased economic reforms and the introduction of rule of law also produced corruption and became the bases of the intensification of corruption in China. In 1989, a large number of students along with civil society and journalists conducted a massive demonstration at Tiananmen Square 
against the increasing corruption and demanded democratic reforms. After the two months of the demonstration, on August 15th, 1989, Chinese government launched a nationwide anti-corruption campaign. Andrew Wedeman writes about the anti-corruption campaign in China that the style of enforcement of anti-corruption campaign in China actually intensified corruption rather than eradicate it. The author symbolizes the Chinese style anti-corruption campaigns with the "Beijing Opera". Chinese Leadership focused on the structural changes and institutional building which may decrease the petty corruption but on the other hand promoted grand corruption. Studies show that the nature of corruption in China is systemic or intensified (Hao \& Johnston, 1995; He, 2000; Sun, 2004). Corruption in China became very serious economic crime in early transition periods of China. Many high ranking officials and low level ministerial officials were charged for being corrupt. ${ }^{\text {xix }}$ Transparency international started its annual base corruption perception index that could perceive the level of corruption. China was among the 2 nd worst country in the list of 96 countries in the first year of the launch on the CPI report in 1996. The score of China was 2.43 out of 10 in 1996, which shows the highest corrupt country in the world. ${ }^{\mathrm{xx}}$ But in the later years it improved slightly but not rapidly as the score in 1997 was 2.88, in 1988, the China's score improved at 3.5 but in the next two years in 1999 and 2000, it fell down to 2.4 and 3.1. In 2001, the score of CPI of China got improved to 3.5. ${ }^{\mathrm{xxi}}$ But this scoring cannot predict the real situation of the corruption in the Country. These are only perceptions of the experts who perceive the level of corruption in the country on the basis of the facts and figures.

A study shows the 20 years data of corruption cases of government officials from 1978 to $2002^{\text {xxii }}$, between 1987 and 1992 , there were 110 provincial and ministerial officials investigated, of whom 79 were from 1990 to 1992 . However, the number of officials in serious cases of corruption and disciplinary sanctions has increased considerably, especially those convicted. Of the 64 high officials, 31 cases of corruption in the database were submitted to the judiciary for rulings, of which only 5 were convicted before 1992 and 26 after 1992. In terms of the amount involved, the number of cases in the 1990s was much higher than in the 1980s. Before 1992, there were no cases of corruption or bribery and the funds reached 100,000 Yuan. After 1992, there were 37 cases in more than 100,000 Yuan, of which 27 cases exceeded 1 million Yuan, of which more than 1.2 million Yuan and 4 cases more than 10 million Yuan. Five cases after 2000 are more than 1 million Yuan. ${ }^{\text {xiii }}$ Of the 54 clear cases, 43 cases began during the period 1988-1995. Meanwhile, the Notice of the Supreme People's Court and the Supreme People's Procuratorate enacted in 1989 announced the Central Government's determination to severely punish corrupt officials. During this time, corruption remains serious, which means that the effective goal of reducing corruption did not completely achieved.

The high number of cases investigated after the 1990s shows the better results in terms of the legal reforms and rule of law in the country. Open market reforms and GDP growth also shows improvement in China during the transition period.

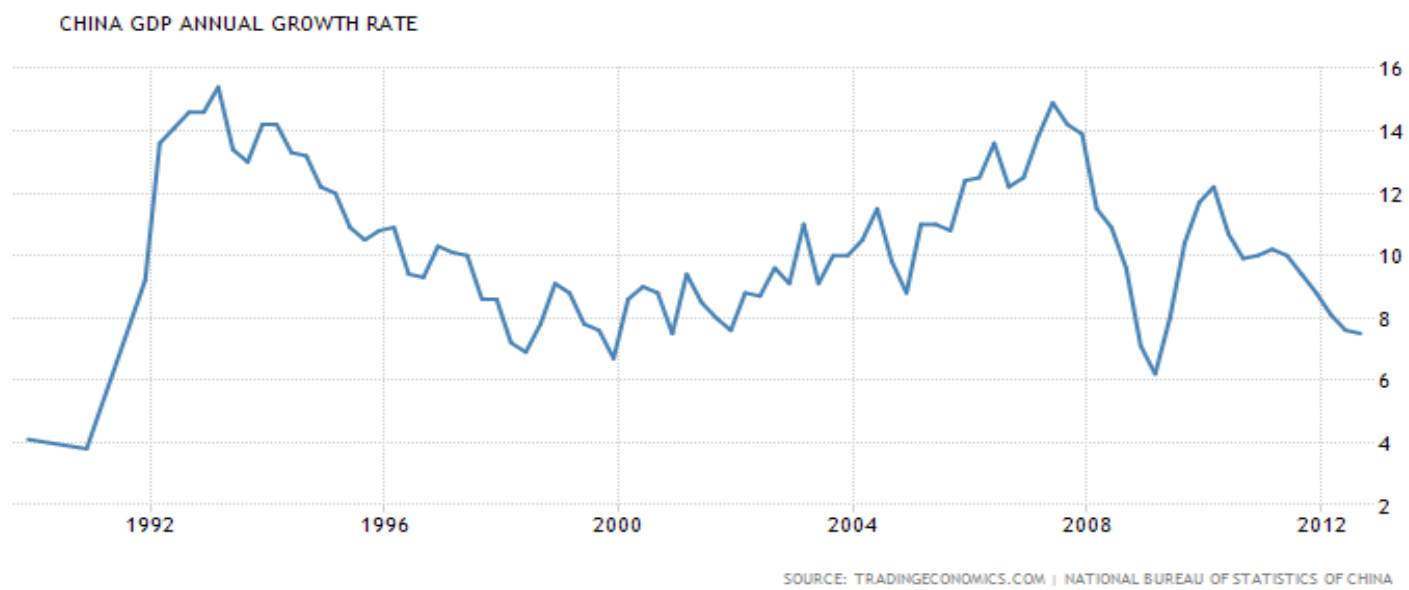

Graph 1. GDP Annual growth of China

Source: Tradingeconomics.com, National Bureau of Statistics of China

This line graph shows the trend of changes in GDP growth rate of China till 2012. The growth rate of the GDP in the 1980s was very high with the highest GDP growth rate of 15.2 in 1984 in the history of China. ${ }^{\text {xxiv }}$ Before 1984 the GDP growth rate was not much high and in the late 80s and early 90s, it increased with decreasing rate as compared to 1984 and 1985. The line shows the highest increase in the GDP growth Rate of 2007 at 14.2 after 1984. After 2007, due to the global financial crises, known as the "worst economic crises" after the great depression of the 1930s, the GDP growth of China increases with decreasing rate. 
Compared to Deng's predecessor, Jiang Zemin, Hu Jintao leadership paid more attention to the welfare of the vulnerable groups' i-e the peasants and the unemployed sector in the reform process. The first three years of President Hu's Political slogans were "people-oriented" and "construction of Harmonious society."

By analyzing the above-mentioned arguments and facts, we may conclude that the corruption, rule of law and economic growth are positively correlated with each other. The theoretical discussion in this section justifies the empirical results obtained in the previous section. Rule of law has played its role as a mediator between the corruption prevention and economic growth in China. As with the increase in the GDP growth rate, a number of corruption cases also increases and at the same time to foster the rule of law, the anti-corruption campaign started and the number of investigations increased. The author will see their relationship in the Xi Jinping era in the next section to reach the final conclusion.

\section{Rule of Law and Corruption in China after 2012}

This section of the paper summarizes and reviews the condition of corruption, rule of law and economic growth after the 18th CPC national congress, 2012 (herein after referred as Xi Jinping era). In the past five years, China's anti-corruption work has taken a new stage and punished almost 1.54 million people, including 440 employees of the central administration. Yang Xiaodu, deputy secretary general of the Communist Party of China, said that over the past five years, disciplinary inspection and supervision departments across the country handled a total of more than 1.55 million corruption cases and handed over more than 58,000 organs, judicial bodies ${ }^{\mathrm{xxv}}$.Current general secretary of the CPC and the president of China, Xi Jinping started a very strict anti-corruption campaign and put forward a five year agenda to combat corruption with zero tolerance policy and run the government under the rule of law. The rule of law with socialist characteristics has been a re volving term throughout the Chinese history. The 18th CPC conference is very important in terms of the practice of the rule of law by introducing the anti-corruption campaign against corrupt government officials in China. CPC leadership launched an "eight point's guideline" in late 2012 that prohibited the use of public funds to buy gifts, hold banquets, pay for vacations and luxurious things. The Central Commission for Disciplinary Inspection now implements the monthly system of rules and regulations within the provincial government, the central party and government bodies, central state-owned enterprises and central financial institutions. These eight provisions are made to combat corruption and to strengthen the party. In 2013, at the 2nd plenary session of the 18th CPC congress, Xi Jinping introduced the term of "Tigers and flies" for the high rank and low rank government officials. He put forward the agenda of target the corrupt officials from top to grass root level. The practice of the rule of law reflect from the actions of government when Zhou Yongkang, among the "tigers" arrested, a member of the Standing Committee of the Political Bureau of the CPC Central Committee, was the head of China's judicial and security system. Former generals and vice president; Guo Boxiong and Xu Caihou, both were members of the Central Military Commission. As for the "flies," Yang said there are 8,900 city level officials, 63,000 county-level officials and 278,000 grassroots party members and officials punished in last five years. ${ }^{\text {xxvi }}$ In 2013 , the government carried out the discipline inspection system reforms and also mobilized the masses to participate in supervision and reporting system. In the same year, a website of central commission of discipline inspection has been launched for the external release of information. Through this website, China has broadened channels for information disclosure, open door policy by encouraging public participation and supervision in accordance with the law. CCDI website is a platform for citizens to participate in anti-corruption reforms along with the government. The mobile application of CCDI website has been launched by government in 2015 and the official account on we chat ${ }^{\mathrm{xxvii}}$ opened in 2016 to make it convenient for the citizens to get updates about the anti-corruption campaign. According to the statistics, the daily average use of the website is over 3 million and accumulated visit exceeded 2.2 billion. The mobile application of CCDI has 3.08 Million installations, with 35 million visits. Similarly, we chat official account of CCDI has 1.03 million followers and altogether 8.26 million hits ${ }^{\mathrm{xxv} i i i}$. In this way public participation in anti-corruption activities increased and databases are available on the website. A special column on the website is opened for the suggestions and opinions of the citizens so that the CCDI's work could be further improved. Xi Jinping anti-corruption campaign put focus on the improvement of report filing system. Supervision for public opinion is considered as 'sword' for the fight against corruption since 18th CPC congress. News media is also encouraged to participate in the report filing and supervision of misconduct. For this purpose, watch station of the four forms of decadence" or "four winds" "xxix is opened in major news media, where typical cases are published as a means of deterrence. Moreover, news media and new technologies are employed for the convenience of the public in filing reports. According to the statistics, the reports of corruption through internet include $50 \%$ of all reports and we chat contain one-third of all. ${ }^{\mathrm{xx}}$ In the end of 2013, Xi Jinping government established and improved the work program on punishing and preventing corruption program 2013-2017. According to this five years planning of anti-corruption work, the government under the rule of law and the socialist practice with Chinese characteristics are main agendas. Party's scientific construction, clean party conduct and strengthening the governance system are also part of the work plan. The focus of the Xi Jinping anti-corruption campaign is on the prevention and punishment of corruption. The campaign also put the focus on the strengthening CPC roots and promoting socialism with Chinese characteristics. Breach of the party 
discipline is strictly investigated with zero tolerance. The other focused areas include the issue of handling the cases seriously, strengthening the international cooperation against corruption, put the focus on the governance structure, accountability and responsibility. Procurement processes made transparent and project inspections strongly investigated. Cadres and leaders are responsible to report any misconduct relevant to procurement and strengthen the system of supervision on the exercise of power. In March 2014, the government focused on the cleaning up the "naked officials"xxxi and issued the list of 100 fugitives fled the country. In 2015, government started the "sky net operation" ${ }^{\text {xxxii }}$ and Between January 2014 and November 2016, 2,442 Chinese fugitives suspected of economic crimes, including 397 officials, were deported from more than 70 countries and regions, and 8.5 billion Yuan were seized in illegal assets, according to the Communist Party of China's Central Commission for Discipline Inspection (CCDI), the country's top anti -graft watchdog. In 2016, alone, 908 fugitives, including 122 officials, were extradited from overseas and 2.3 billion Yuan recovered in illegal assets. A total of 48 people, named as China's top 100 fugitives repatriated to China. ${ }^{\text {xxiii }}$

According to the statistics of the reporter from the sea bureau, as of December 30, 2016, there were 36 officials above the rank of deputy minister who fell to investigation this year, 41 people were trialled and 36 sentenced the highest in nearly three years. Since the 18th CPC National Congress, the number of public officials above the deputy de partmental level or above is 124, of whom 56 have been sentenced, 17 have been downgraded by administrative dismissal, and 2 have died of illness. The proportion of cases closed is $61 \%$ and $63 \%$ brought to judicial proceedings. ${ }^{\text {xxiv }}$ Along with the corruption prevention and punishment initiative, Xi Jinping government also put the focus on the strengthening of the rule of law as mentioned above. In his speech on the $4^{\text {th }}$ plenary session of the $18^{\text {th }} \mathrm{CPC}$ central committee he mentioned the Hen Fei words as: "if conformers to law are strong, the country is strong; if conformers to law are weak, the country is weak" ${ }^{\mathrm{xxxv}}$. If we review the rule of law progress in past five years (Xi Jinping era), there are remarkable achievements in terms of rule of law promotion. The main focus of the $18^{\text {th }} \mathrm{CPC}$ central government is promoting the scientific legislation, strict law enforcement, judicial reforms and justice, and observance of the law by all citizens. From 2013 to June, 2017, 20 new laws enacted and 39 resolutions in law amendment, which involve 100 laws. According to the statistics, by the end of April 2017, 369 local laws and regulations have been approved in the cities or prefectures newly conferred the legislative power. Moreover, to enhance the democratic legislation, 4 contact points were set up in Hebei, Jiangxi, Gansu, and Shanghai to solicit grassroots opinion, which has completed 988 suggestions on 22 draft bills by the end of July 2017. As Xi Jinping addressed the central political and legal work conference on Jan 7,2014, he said: "we must be law enforcers who know, understand, abide by, and uphold rule of law, stand firmly on our feet and straighten our backs, obey only the facts and the law, and be relentless and impartial in the enforcement of the law." $x \times x v i$

Xi Jinping put more focus on the strict enforcement of the law in different sectors such as environmental protection and telecom fraud. ${ }^{\text {xxxvii }} \mathrm{He}$ also focused on the judicial justice by saying: the negative impact of a wrongly judged case is enough to destroy the good image created by 99 fairly judged cases. Even one error in 10,000 cases means a 100 percent hurt to the victim". xxxviii Since the $18^{\text {th }}$ CPC National Congress, judicial organs have redressed 34 major cases which were mishandled. ${ }^{\text {xxix }}$ Another step towards the practice of the rule of law is the open trials and live streaming of trials. Since 2016, 600,000 trails have gone online, received 2 billion views and 30 million judgment documents uploaded on the website, China judgment online, with 10 billion page views, making the website the largest of its kind in the world. ${ }^{\mathrm{xl}}$ while addressing to a group study session of the political bureau of the CPC central committee on $23^{\text {rd }} \mathrm{Feb} 2013$, Xi said: " officials are required to exemplify abiding by the law, state organs are responsible to raise legal awareness, convenient legal services and involvement of all."xli

When we analyze the situation of economic growth since the $18^{\text {th }} \mathrm{CPC}$ national congress, the results show that there is a shift in the growth of the economy. We can observe from the bar chart below: 


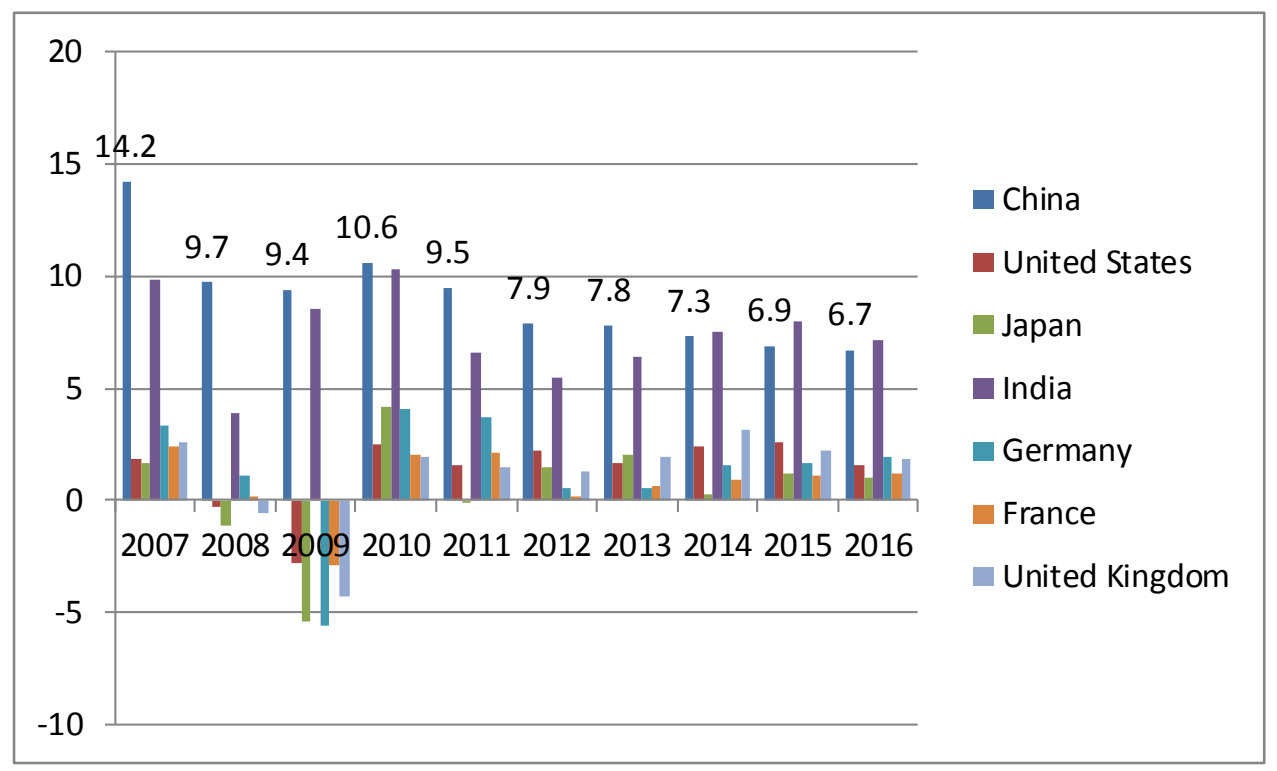

Source: World Development Indicators ${ }^{\text {xlii }}$

Chart 1. Annual GDP growth

According to World Bank data, the GDP growth rate of China is highest amongst the other top economies of the world. But we can see from the figure that the GDP growth rate is not stable after the 2007 economic downfall and after 2012, during the Xi Jinping era the GDP growth rate of China is decreasing and growth rate of India after 2012 is increased as compared to China. Although the current growth rate of the economy is lower than the government target as 7\%, still China is the second largest economy in the world. Wealth in China is doubled as compared to 2006 and the Chinese person is twice well off now as they were in 2006. . $^{\text {liii }}$ A rebalance in China's economy has been observed from industry to services. In 2006 the share of industry to GDP growth was 13\% higher than the services. In latest breakdown, the share of services is $13 \%$ more than industry. China is becoming more self-reliance as the exports share to GDP is $35 \%$ and imports dropped from $29 \%$ to $19 \%$ in the same period. General Secretary Xi Jinping pointed out in the 19th CPC National Congress report: "China's economy has shifted from a phase of rapid growth to a phase of high-quality development." The stage of high-quality development show the following phased features: First, economic growth has gradually decreased from the rapid growth of about $9 \%$ in the past to about $6 \%$ of the current growth. Second, China must shift to a model that pursues high-quality and cost-effective growth. Third, it must speed up the marketization reform that is conducive to giving full play to the role played by the market in allocating resources. The quality of growth is linked to the improvement in governance and rule of law.

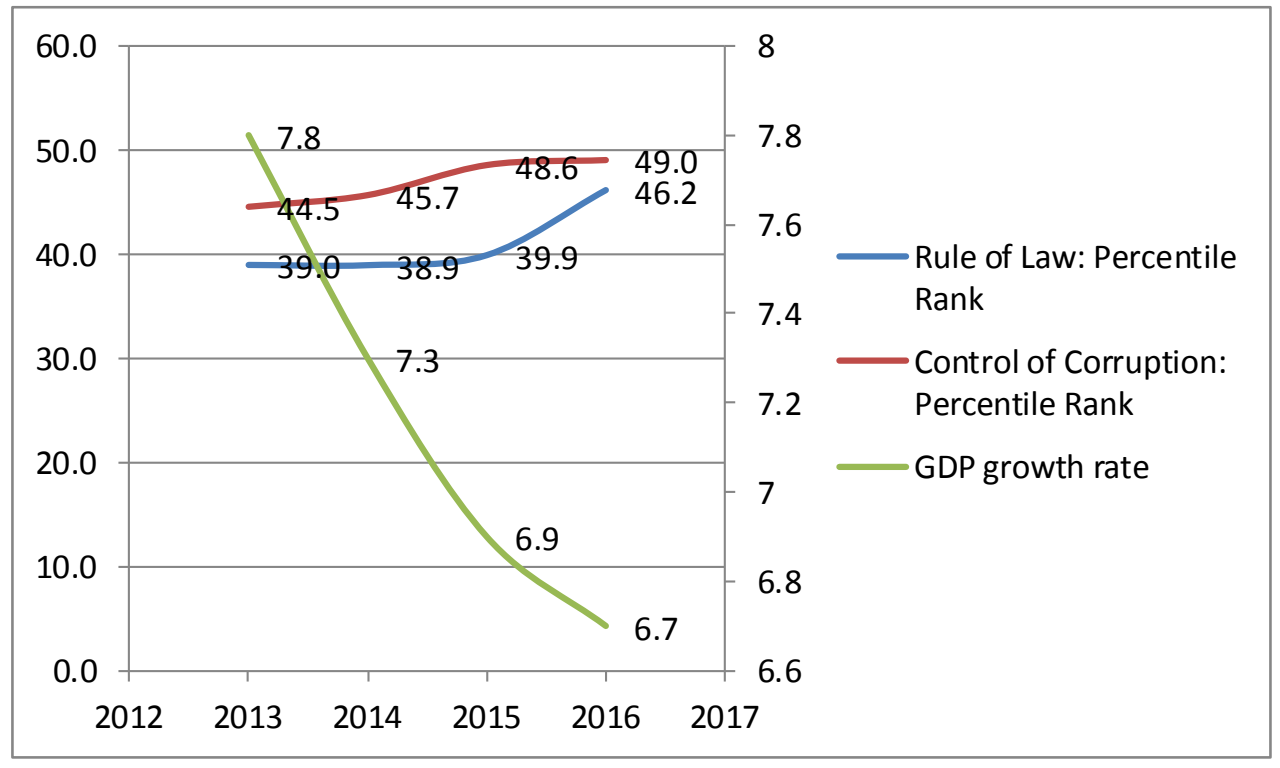




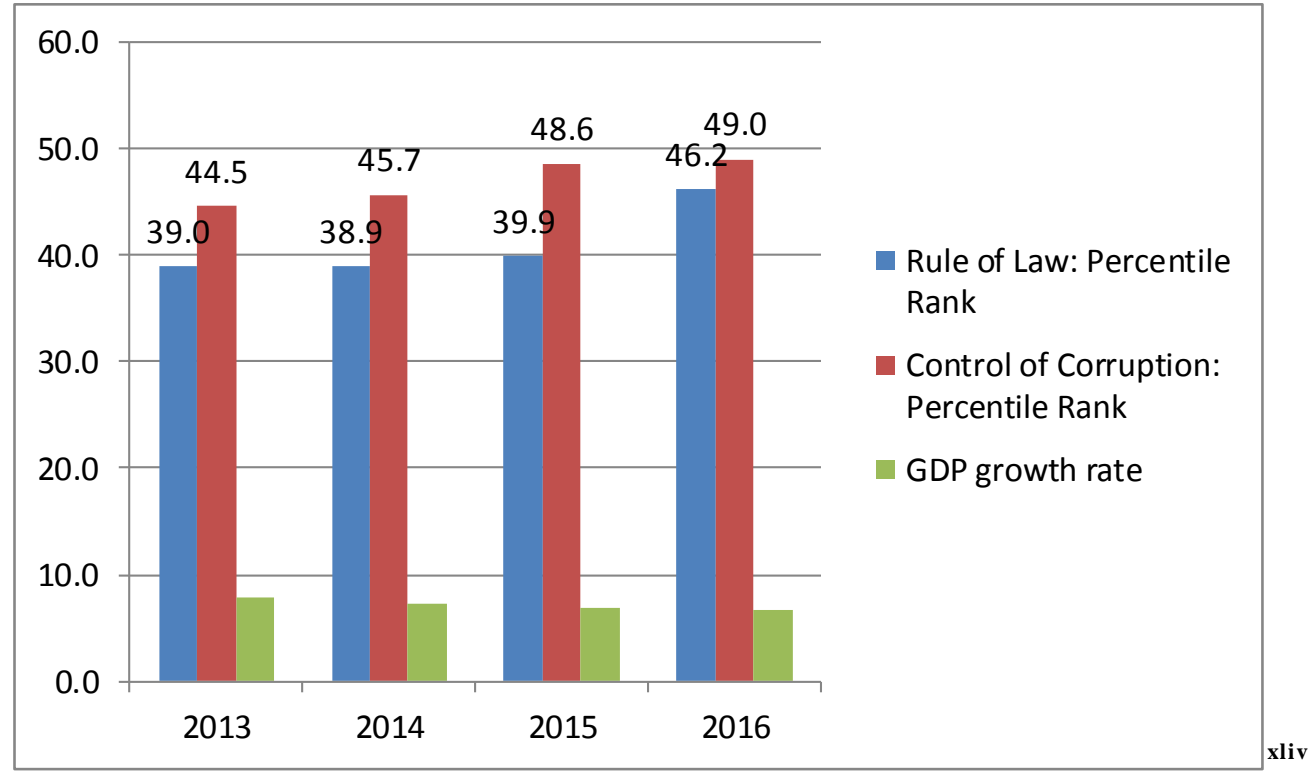

Chart 2, 3. Rule of law, Control of corruption and Economic growth rate in China from 2012-16

Source: World Development Indicators

The abo ve charts 2 and 3 show the ranking of the rule of law control of corruption and the GDP growth rate of China since Xi Jinping era. The lines show that the ranking of both indicators rule of law and control of corruption is increasing and getting improved day by day. The growth rate of the economy is going down from $7.8 \%$ in 2013 to $6.7 \%$ in 2016 .

The concept of the new economic development model has been discussed in the latest $19^{\text {th }} \mathrm{CPC}$ conference to address and combat the imbalances in growth. The report of the 19th National Congress of the CPC didn't raise the target of doubling GDP. The purpose is to better implement the new development concept, solve the problem of insufficient development imbalance, and promote the all-round development of the cause of the party and the state. The same report stated the goal of the CPC to deepening the reforms and to achieve the target of government under the rule of law by 2035 . $^{\text {xlv }}$

In the $19^{\text {th }} \mathrm{CPC}$ conference, $\mathrm{Xi}$ Jinping presented his five years report of anti-corruption campaign and rule of law progress. He promised to continue his fight against corruption and practice of the rule of law during the next five years of his reign. To achieve his goal he envisioned the four themes in the war against corruption in the next five year. Xi pledged to preserve a never-ending war against corruption in China. "Only when we make sure that officials are honest, the government is clean and political affairs are handled with integrity, can we avoid history's cycle of rising and fall and ensure the CPC's long-term stability," Xi warned.

He announced to introduce a new corruption law soon so that the corrupt practices abide according to law. Xi Jinping stressed that state power should be placed in the coverage of the institution and the establishment of supervision committees at the national, provincial, municipal and county le vels are needed. The supervisory committee will work closely with the Central Commission for Discipline Inspection. Establish a platform for corrupt reporting that both agencies share corruption investigations and case information. Xi Jinping said both agencies will ensure that supervision law covers every person exercising public authority.

Xi Jinping also said that in addition to institutional mechanisms, it will also develop a national monitoring law, supervision agencies act according to law. More importantly, Xi Jinping said the practice of "shunggui" will be replaced with detention. Supervisory bodies must be abiding by the laws.

\section{Conclusion}

This paper is based on the study of the relationship between corruption, rule of law and economic growth in China. The author considered the rule of law as a mediating factor between corruption prevention and economic growth because of the strong link between these three variables in transitional China. The study has two hypotheses, first assumed that economic development can raise the level of prevention of corruption. Secondly, the Rule of law plays an intermediary role in the process of economic development that increases the impact of corruption prevention or control of corruption. To verify or check the hypothesis, a mediation model is used by applying regression analysis on the basis of these two assumptions. The results showed that the level of prevention and control of corruption have a positive effect on the economic growth as some other studies also drawn the same conclusion. (Gupta, 2002 ;Gyimah-Brempong, 2002;Mo, 
2001 ;Podobnik, 2008)and thus verified hypothesis 1. Results showed that economic growth can significantly raise the rule of law and the rule of law can significantly improve the level of prevention and control of corruption. Moreover, results indicated that the level of Rule of law plays a partial intermediary role in the process of economic development to enhance the impact of prevention and control of corruption. After verifying the relationship between three variables statistically, rule of law and corruption reforms have been discussed in detail in the last two sections. The facts and figures show that the rule of law and corruption prevention efforts have been increasing and slightly becoming better since 2013, in the Xi Jinping era. We may conclude that Xi Jinping's anti-corruption movement effect is very significant, but there are still signs of suspicious political retaliation by some critics. Although the anti-corruption high-pressure situation has been formed, it can be seen that the problem of corruption still exists and the anti-corruption struggle situation remains harsh and complicated. As long as the righteous thoughts are not stopped and the anti-corruption and malice are not softened, China can certainly win the battle against corruption and build a clean government under the rule of law that can never be lost. At the end, we may conclude that anti-corruption and rule of law reforms speed still need lasting force. Anti-corruption and rule of law need fast forward move to achieve the goals set by $19^{\text {th }} \mathrm{CPC}$ central committee.

\section{Acknowledgement}

The corresponding author would like to acknowledge her colleague Sumaira Kayani for her continued support and help throughout the research. I would like to mention that this research has been supported by the Key Project of the national "2011 Plan" Collaborative Innovation Center of Judicial Civilization; The Ministry of Education's Major Projects in Philosophy and Social Sciences Research, "Research on a System of Indicators for China's Construction of a Rule of Law Government" (13JZD011) and a Major Project of the National Social Science Fund "Research on Indicators of Judicial Transparency" (13AFX01).

\section{References}

Ades, A., \& Di Tella, R. (1997). The new economics of corruption: a survey and some new results. Political Studies, 45(3), 496-515. https://doi.org/10.1111/1467-9248.00093

Ahmet, Y. (2012). Inflation and corruption relationship: Evidence from panel data in developed and de veloping countries. International Journal of Economics and Financial Issues, 2(3), 281.

Aidt, T., Dutta, J., \& Sena, V. (2008). Governance regimes, corruption and growth: Theory and evidence. Journal of Comparative Economics, 36(2), 195-220. https://doi.org/10.1016/j.jce.2007.11.004

Bayar, G. (2011). Causes of corruption: dynamic panel data analysis of some post-Soviet countries and East Asian countries. Journal of Applied Business Research, 27(1), 77. https://doi.org/10.19030/jabr.v27i1.912

Berkman, Ü. (1988). Yolsuzluk ve Rüşvete Karşı Önlemler. Journal of Economics and Administrative Studies, 2(1), 39-56.

Bertot, J. C., Jaeger, P. T., \& Grimes, J. M. (2010). Using ICTs to create a culture of transparency: E-government and social media as openness and anti-corruption tools for societies. Government information quarterly, 27(3), 264-271. https://doi.org/10.1016/j.giq.2010.03.001

Blasek, K. (2015). Rule of law in China: A comparative approach: Springer.

Broadman, H. G., \& Recanatini, F. (2001). Seeds of corruption-Do market institutions matter? MOST: Economic Policy in Transitional Economies, 11(4), 359-392. https://doi.org/10.1023/A:1015264312632

Carothers, T. (1998). The rule of law revival. Foreign Aff. 77,95. https://doi.org/10.2307/20048791

Carothers, T. (2003). Promoting the rule of law abroad: the problem of knowledge.

Dridi, M. (2014). Corruption and education: Empirical evidence. International Journal of Economics and Financial Issues, 4(3), 476.

Goel, R. K., \& Rich, D. P. (1989). On the economic incentives for taking bribes. Public choice, 61(3), 269-275. https://doi.org/10.1007/BF00123889

Goldsmith, A. A. (1999). Slapping the grasping hand. American Journal of Economics and Sociology, 58(4), 865-883. https://doi.org/10.1111/j.1536-7150.1999.tb03398.x

Gyimah-Brempong, K. (2002). Corruption, economic growth, and income inequality in Africa. Economics of Governance, 3(3), 183-209. https://doi.org/10.1007/s101010200045

Habermas, J. (1996). Between facts and norms: Contributions to a discourse theory of law and democracy: MIT Press.

Hao, Y., \& Johnston, M. (1995). China's surge of corruption. Journal of Democracy, 6(4), 80-94. https://doi.org/10.1353/jod.1995.0068 
He, Z. (2000). Corruption and anti-corruption in reform China. Communist and Post-Communist Studies, 33(2), 243-270. https://doi.org/10.1016/S0967-067X(00)00006-4

June, R., Chowdhury, A., Heller, N., \& Werve, J. (2008). A User's Guide to Measuring Corruption. Oslo: UNDP and Global Integrity.

Karagöz, K., \& Karagöz, M. (2010). Yolsuzluk, Ekonomik Büyüme Ve Kamu Harcamaları: Türkiye İçin Ampirik Bir Analiz. Sayıştay Dergisi, 76(1-3), 5-22.

Kaufmann, D., Kraay, A., \& Mastruzzi, M. (2006). Governance matters V: aggregate and individual governance indicators for 1996-2005 (Vol. 4012): World Bank Publications. https://doi.org/10.1596/1813-9450-4012

Lee, R. P. (1981). The folklore of corruption in Hong Kong. Asian Survey, 355-368. https://doi.org/10.1525/as.1981.21.3.01p02592

Mainemelis, C., Kark, R., \& Epitropaki, O. (2015). Creative leadership: A multi-context conceptualization. Academy of Management Annals, 9(1),393-482. https://doi.org/10.1080/19416520.2015.1024502

Mo, P. H. (2001). Corruption and economic growth. Journal of Comparative Economics, 29(1), 66-79. https://doi.org/10.1006/jcec.2000.1703

Mundial, B. (2013). China 2030: building a modern, harmonious and creative society. Genebra: Banco Mundial.

North, D. C. (1991). Institutions. Journal of economic perspectives, 5(1), 97-112. https://doi.org/10.1257/jep.5.1.97

O'Donnell, G. A. (2004). Why the rule of law matters. Journal of Democracy, 15(4), 32-46. https://doi.org/10.1353/jod.2004.0076

Ozpolat, A., Guven, G. G., Ozsoy, F. N., \& Bahar, A. (2016). Does Rule of Law Affect Economic Growth Positively? Research in World Economy, 7(1), 107. https://doi.org/10.5430/rwe.v7n1p107

Peerenboom, R. (2002). China's long march toward rule of law: Cambridge University Press. https://doi.org/10.1017/CBO9780511493737

Pelizzo, R., \& Stapenhurst, R. (2004). Tools for legislative oversight: An empirical investigation.

Podobnik, B., Shao, Jia,Njavro, Djuro,Ivano v, Plamen Ch, \& , S., H Eugene. (2008). Influence of corruption on economic growth rate and foreign investment. The European Physical Journal B-Condensed Matter and Complex Systems, 63(4), 547-550. https://doi.org/10.1140/epjb/e2008-00210-2

Przeworski,A., \& Maravall, J. M. (2003). Democracy and the Rule of Law (Vol. 5): Cambridge University Press.

Rigobon, R., \& Rodrik, D. (2005). Rule of law, democracy, openness, and income. Economics of transition, 13(3), 533-564. https://doi.org/10.1111/j.1468-0351.2005.00226.x

Samuels, K. (1998). Rule of Law Reform in Post-Conflict Countries. Paper presented at the Operational Initiatives and Lessons Learnt. Social Development Papers, Conflict Prevention \& Reconstruction, Paper.

Santoro, E. (2007). The Rule of Law History, Theory and Criticism (Vol. 80): Springer Science \& Business Media.

Sun, Y. (2004). Corruption and market in contemporary China: Cornell University Press.

Sung, H.-E. (2004). Democracy and political corruption: A cross-national comparison. Crime, Law and Social Change, 41(2), 179-193. https://doi.org/10.1023/B:CRIS.0000016225.75792.02

Swamy, A., Knack, S., Lee, Y., \& Azfar, O. (2001). Gender and corruption. Journal of development economics, 64(1), 25-55. https://doi.org/10.1016/S0304-3878(00)00123-1

Treisman, D. (2000). The causes of corruption: a cross-national study. Journal of public economics, 76(3), 399-457. https://doi.org/10.1016/S0047-2727(99)00092-4

Van Rijckeghem, C., \& Weder, B. (2001). Bureaucratic corruption and the rate of temptation: do wages in the civil service affect corruption and by how much? Journal of development economics, 65(2), 307-331. https://doi.org/10.1016/S0304-3878(01)00139-0

Zakaria, E. (2009). Promoting cooperative learning in science and mathematics education: A Malaysian perspective. Colección Digital Eudoxus(22).

\section{Endnote}

\footnotetext{
${ }^{i}$ Access from world bank website: http://www.worldbank.org/en/country/china/overview

${ }^{\text {ii }}$ Full text of President Xi's address to the media. (2012-11-16). News, China daily, p. 1. Retrieved from
} 
http://www.chinadaily.com.cn/china/2012cpc/2012-11/16/content_15934514.htm

iii $\mathrm{Li}$ (理, pinyin lǐ) is a concept found in Neo-Confucian Chinese philosophy. It refers to the underlying reason and order of nature as reflected in its organic forms. It may be translated as "rational principle" or "law." Fa (Chinese: 法; Mandarin pronunciation: [fà]) is a concept in Chinese philosophy that covers ethics, logic, and law. It can be translated as "law" in some contexts, but more often as "model" or "standard." First gaining importance in the Mohist school of thought, the concept was principally elaborated in Legalism.

${ }^{\text {iv }}$ See Constitution of China: Article 5. The state upholds the uniformity and dignity of the socialist legal system. No law or administrative or local rules and regulations shall contravene the constitution. All state organs, the armed forces, all political parties and public organizations and all enterprises and undertakings must abide by the Constitution and the law. All acts in violation of the Constitution and the law must be investigated. No organization or individual may enjoy the privilege of being above the Constitution and the law.

${ }^{v}$ See: (Peerenboom, 2002)

${ }^{v i}$ Accessed from the World Bank database: Countries included, China, France, Germany, India, Japan, U.S.A, U.K, as top seven economies.

${ }^{\text {vii }}$ See worldwide governance indicators and rule of law index in which corruption and rule of are used as indicators to evaluate the governance level of countries.

viii Accessed from: www.europeanchamber.com, dated 17/11/2017

${ }^{\text {ix }}$ Ibid

${ }^{x}$ ibid

${ }^{x i}$ Constitution of China: Article 5. The state upholds the uniformity and dignity of the socialist legal system. No law or administrative or local rules and regulations shall contravene the constitution. All state organs, the armed forces, all political parties and public organizations and all enterprises and undertakings must abide by the Constitution and the law. All acts in violation of the Constitution and the law must be investigated. No organization or individual may enjoy the privilege of being above the Constitution and the law.

xii Ibid

xiii Accessed from Eckholm, E. (2000, 21 November). China Signs U.N. Pact on Rights and Rule of Law, New York Times.

xiv See: (Blasek, 2015)

${ }^{x v}$ See Government, C. (Feb 28, 2008). China's Efforts and Achievements in Promoting the Rule of Law. Retrieved from http://www.china.org.cn/government/news/2008-02/28/content_11025486.htm

xvi Accessed from: https://treaties.un.org/pages/ParticipationStatus.aspx?clang=_en, dated 11/20/2017

xvii Scientific notation, representing 4.61 X10 ${ }^{-5}$ Remain constant ahead.

xviii ibid

xix http://www.china.org.cn/english/2003/Jun/66715.htm

${ }^{x x}$ Access from the 1996 report of CPI: https://www.transparency.org/files/content/tool/1996_CPI_EN.pdf

xxi Reports of 1997, 1998,1999, 2000 and 2001 of CPI:

xxii Ibid-15

xxiii ibid

xxiv Retrieved from: Tradingeconomics.com, National Bureau of statistics of China

${ }^{x x v}$ See: Lam, W. (2016). Chinese politics in the Hu Jintao era: New leaders, new challenges: Routledge.

xxvi ibid

xxvii A Chinese social networking app.

xxviii Retrieved from UN Documents: China's Successful Practices on its Public and Transparent Anti-Corruption Campaign, Aug, 2016, https://www.unodc.org 
${ }^{x x i x}$ \{NOTE: The CPC faces "four forms of decadence" in its ranks - formalism, bureaucratism, hedonism, and extravagance.Formalism refers to doing things for form's sake, separating action from knowledge, neglecting what is practical and effective, and resorting to deceit.

Bureaucratism refers to departing from reality and losing touch with the people. Hedonism refers to mental laxity and resting on one's laurels.Extravagance refers to waste and a dissolute and decadent lifestyle.\}

xxx ibid

xxxi The name is applied to Chinese civil servants who have sent family members to live abroad

xxxii China is using an operation called 'Skynet' to track down fugitive corrupt officials

xxxiii CCTV news, "Anti-corruption drive sees billions in illegal assets seized" 2016-12-10, retrieved from, http://chuansong.me/n/1273595651760

${ }^{x x x i v}$ Retrieved from Chinese News: http://news.sohu.com/20161231/n4774433513.shtml

${ }^{x x x v}$ Han Fei, 280-233 BC; cited by president xi Jinping, at the 4 th plenary session of $18^{\text {th }}$ CPC central committee.

${ }^{x x x v i}$ Said by president Xi in the central political and legal work conference on Jan 7, 2014.

xxxvii ibid

xxxviii Xi Jinping addressed in his speech, Jan 7, 2014.Retrieved from http://en.people.cn/90785/8507456.html

xxxix ibid

${ }^{\mathrm{x} 1}$ Retrieved from china's trials live streaming website: http://tingshen.court.gov.cn/

xli Retrieved from: http://www.chinadaily.com.cn/m/chinalic/2017-09/07/content_31902656.htm

xlii Accessed from

http://databank. worldbank.org/data/reports.aspx?Code=NY.GDP.MKTP.KD.ZG\&id=1ff4a498\&report_name=Popular-I ndicators \&populartype $=$ series $\&$ ispopular $=\mathrm{y}$

xliii https://www.weforum.org/agenda/2016/06/how-has-china-s-economy-changed-in-the-last-10-years/

xliv Source: world bank data of world governance indicators: Accessed from, http://info.worldbank.org/governance/wgi/wgidataset.xlsx

xlv Retrieved from: http://news.xinhuanet.com/english/special/2017-11/03/c_136725942.htm

\section{Copyrights}

Copyright for this article is retained by the author(s), with first publication rights granted to the journal.

This is an open-access article distributed under the terms and conditions of the Creative Commons Attribution license which permits unrestricted use, distribution, and reproduction in any medium, provided the original work is properly cited. 